\title{
ANALISIS BIAYA DIFERENSIAL UNTUK MENGAMBIL KEPUTUSAN MENJUAL LANGSUNG ATAU MEMPROSES LEBIH LANJUT PRODUK PADA INDUTRI KACANG SANGRAI TARSIUS
}

\author{
Oleh : \\ Ellis Fanny Manginsihi ${ }^{1}$ \\ David. Paul Elia Saerang² \\ Rudy J. Pusung ${ }^{3}$ \\ Fakultas Ekonomi dan Bisnis \\ Universitas Sam Ratulangi Manado \\ Email: ${ }^{1}$ elismanginsihi04101992@gmail.com
}

\begin{abstract}
One of the functions of management is planning. Managers are faced with decisions regarding the selection of various kinds of alternatives. Any decisions taken by management will be a measurement of the success of a company in the future. One way to avoid mistakes in decision-making is by using differential analysis. Where the differential cost analysis is an approach to the analysis of the relevant costs are focused on different charges in a series of alternatives. The purpose of this study is to provide information that is relevant for the business owner to determine what costs and revenues arising from each alternative and compare to see the profits generated between direct selling or further memprosek product. The results showed that if the owner of the Industri Kacang Sangrai Tarsius wants to expand its business by choosing alternative further processing can be applied if the product is further processed products, the revenue that will be received more than if directly sell the product.
\end{abstract}

Keywords : Cost Differential, Decision, Or the Direct Selling Process More Products

\section{PENDAHULUAN}

\section{Latar Belakang}

Umumnya dalam menjalankan suatu usaha entah itu usaha berskala besar atau kecil, bertujuan untuk memperoleh laba yang sebesar-besarnya dari kegiatan usaha yang dilakukan. Hal itu mendorong para manager untuk memikirkan bagaimana caranya agar produk yang diproduksi bisa memberikan pendapatan yang lebih dari biasanya. Salah satu cara yang dilakukan adalah dengan membuat inovasi atau alternatif-alternatif baru pada produk yang akan diproduksi kedepan yaitu memberikan kualitas produk yang lebih baik dari sebelumnya.

Manager harus menganalisis atau memperhitungkan biaya yang akan dikeluarkan jika ingin melakukan hal tersebut karena mungkin hanya menambah biaya saja dan mungkin tidak memberikan laba yang lebih. Manager tidak bisa langsung memutuskan untuk menjalankanya, manager harus memperhitungkan terlebih dahulu biaya-biaya apa saja yang akan timbul jika ingin menjalankan alternatif tersebut dan apakah dengan menjalakan alternatif tersebut produknya bisa lebih memberikan pendapatan atau laba yang lebih dari produk yang diproduksi sebelumnya.

Salah satu cara agar tidak terjadi kesalahan dalam pengambilan keputusan adalah dengan cara menggunakan analisis biaya diferensial. Dimana analisis biaya diferensial (differential cost analysis) adalah pendekatan terhadap analisis biaya relevan yang berfokus pada biaya yang berbeda dalam serangkaian alternatif. Keputusan yang paling menguntungkan adalah alternatif dengan beban yang paling rendah. Manakala sebuah keputusan akan mempengaruhi baik pendapatan maupun beban, manager harus mengetahui jumlah setiap perubahan guna menaksir perubahan laba operasi. 
Industri Kacang Sangrai Tarsius yaitu salah satu usaha yang berada di kawongkoan yang bergerak dibidang industri kacang sangrai. Usaha ini telah bergerak sejak tahun 1989 dan sampai pada saat ini produk yang dihasilkan hanya kacang yang di sangrai. Karena semakin hari semakin banyak persaingan yang ada maka pemilik usaha ini ingin mengembangkan usahanya agar mendapatkan laba/pendapatan lebih dari sebelumnya.

Industri Kacang Sangrai Tarsius memikirkan berbagai alternatif untuk dapat mengembangkan usahanya antara lain dengan memproses lebih lanjut kacang yang sudah di sangarai untuk di olah menjadi kacang gula. Apakah dengan memproses lebih lanjut kacang yang telah di sangrai bisa menghasilkan laba/pendapatan yang lebih dari sebelumnya yang langsung menjualnya. Industri Kacang Sangrai Tarsius belum melakukan pengambilan keputusan. Maka dalam penelitian ini peneliti akan melakukan penelitian dengan judul "Analisis Biaya Diferensial Untuk Keputusan Menjual Langsung Atau Memproses Lebih Lanjut Produk Pada Industri Kacang Sangrai Tarsius“.

\section{Tujuan Penelitian}

Tujuan dari penelitian adalah untuk mengetahui apakah keputusan yang diambil dari Industri Kacang Sangrai Tarsius sudah tepat dengan menggunakan analisis biaya diferensial.

\section{TINJAUAN PUSTAKA KonsepAkuntansi}

1. Definisi akuntansi dapat dilihat dari 2 (dua) sudut pandang yaitu :

a. Definisi dari sudut pemakai

Akuntansi dapat didefinisikan sebagai suatu disiplin yang menyediakan informasi yang diperlukan untuk melaksanakan kegiatan secara efisien dan mengevaluasi kegiatan-kegiatan suatu organisasi.

b. Definisi dari sudut suatu proses kegiatan

Akuntansi dapat didefinisikan sebagai proses pencatatan, penggolongan, peringkasan, pelaporan, dan penganalisisan data keuangan suatu organisasi.

2. Cabang akuntansi terdapat 3 (tiga) cabang akuntansi yaitu :

a. Akuntansi keuangan

b. Akuntansi manajemen

c. Akuntansi pemerintahan

3. Fungsi Akuntansi

sugiarto, (1999 : 54), menyatakan fungsi akuntansi adalah menyediakan laporanlaporan periodik untuk manajemen, investor, kreditur, dan pihak-pihak lain diluar perusahaan.

Ada hal-hal yang perlu diperhatikan mengenai konsep-konsep dasar akuntansi, yaitu sebagai berikut :
a. Kesatuan usaha
b. Dasar-dasar pencatatan
c. Konsep periode waktu
d. Unit moneter
e. Transaksi
f. Kelangsungan usaha
g. Konsep penandingan

\section{Informasi Akuntansi}

Perusahaan khususnya pihak manajemen selalu dihadapkan pada perencanaan dan pengambilan keputusan yang menyangkut berbagai macam alternatif yang harus dipilih. Dalam pengambilan keputusan itu mereka menghadapi ketidakpastian dalam memilih berbagai alternatif. Informasi akuntansi sangat membantu manager dalam proses pengambilan keputusan manajemen untuk mencapai tujuan yang telah ditentukan dan untuk mengurangi ketidakpastian atas alternatif yang dipilih. Agar pembuatan keputusan bisa tepat maka 
diperlukan informasi yang akurat yaitu informasi yang relevan, tepat waktu dan pendapatan melebihi biaya didalam perolehan informasi tersebut.

\section{Informasi Akuntansi Diferensial}

a. Pengertian Akuntansi Diferensial

Mulyadi (2001 : 115), menyatakan “ Informasi akuntansi diferensial adalah taksiran perbedaan aktiva, pendapatan, dan biaya dalam tindakan alternatif tertentu dibandingkan dengan alternatif tindakan lainya".Pengertian informasi akuntansi diferensial diatas, dapat ditarik kesimpulan bahwa informasi diferensial menekankan pada laba diferensialnya, yaitu taksiran perbedaan pendapatan dan biaya dimasa yang akan datang yang dipergunakan untuk menentukan pilihan alternatif tindakan yang terbaik diantara alternatif yang tersedia.

b. Manfaat Informasi Akuntansi Diferensial Dalam Pengambilan Keputusan

- Membeli/membuat sendiri

- Menjual/memproses lebih lanjut suatu produk

- Menghentikan atau melanjutkan produksi produk tertentu

- Menerima/menolak pesanan khusus

c. Peranan Informasi Akuntansi Dalam Pengambilan Keputusan

Informasi akuntansi bukan satu-satunya jenis informasi diferensial yang digunakan dalam pembuatan keputusan. Dengan kata lain, informasi akuntansi hanya merupakan salah satu informasi diferensial yang harus dipertimbangkan. Pembuatan keputusan mempertimbangkan informasi yang sifatnya subyektif dan informasi yang sifatnya obyektif. Informasi subyektif adalah informasi yang diberikan oleh pihak tertentu atas dasar pengalaman dan intuisinya. Informasi subyektif fungsinya sebagai suplemen informasi objektif. Informasi objektif adalah informasi yang disusun atas dasar teknik-teknik yang logis atau oleh pihak yang ahli. Informasi akuntansi merupakan salah satu informasi objektif sehingga informasi akuntansi dapat menambah pengetahuan pembuat keputusan dan dapat mengurangi resiko. Informasi akuntansi yang bermanfaat untuk pembuatan keputusan minimal harus mempunyai tiga karakteristik penting sebagai berikut :

- Diferensial

- Tepat Waktu

- Teliti

d. Tahap- Tahap Proses Pengambilan Keputusan

Untuk pembuatan keputusan digunakan teori keputusan (decision theory). Teori keputusan merupakan ilmu pengetahuan yang menjelaskan proses pembuatan keputusan. Sesuai dengan teori keputusan, proses pembuatan keputusan dapat dibagi menjadi beberapa tahap. Penetapan ini bermanfaat untuk menganalisis masalah secara masuk akal. Tahap - tahap proses pembuatan keputusan adalah :

- Penentuan Masalah

- Identifikasi Alternatif Pemecahan Masalah

- Mengumpulkan Informasi Diferensial

\section{Konsep Akuntansi Manajemen}

Warindrani, (2006:1-2) menyatakan akuntansi manajemen terdiri dari dua kata yaitu akuntansi dan manajemen. Akuntansi sendiri berarti proses pengukuran, analisis, pencatatan dan pelaporan terhadap seluruh kejadian ekonomi. Sedangkan manajemen lebih diartikan pada proses manajemen yang terdiri dari aktivitas perencanaan, pengendalian dan pengambilan keputusan yang dilakukan oleh internal organisasi yaitu manajer dan pegawai yang diberi wewenang dalam mengelola usahanya.

Informasi yang disajikan dalam akuntansi manajemen diharapkan dapat membantu semua fungsi yang ada dalam manajemen organisasi seperti biaya produk, informasi pelanggan, informasi keseluruhan proses dari tiap-tiap fungsi manajemen dan juga obyek penelitian manajemen lainnya sebagai dasar untuk mengidentifikasi dan memberikan solusi atas berbagai masalah yang ada. 


\section{Tipe Dan Manfaat Informasi Akuntansi Manajemen}

Menurut mulyadi (akuntansi manajemen), bahwa informasi akuntansi manajemen dapat dihubungkan dengan objek informasi, alternatif yang akan dipilih dan wewenang manajer. Jika informasi akuntansi manajemen dihubungkan dengan obyek informasi seperti produk, departemen, atau aktivitas, maka akan dihasilkan konsep informasi akuntansi penuh. Jika dihubungkan dengan alternatif yang akan dipilih, maka akan dihasilkan konsep informasi akuntansi diferensial yang sangat diperlukan oleh manajemen dalam pengambilan keputusan pemilihan alternatif.Jika dihubungkan dengan wewenang yang dimiliki oleh manajer dihasilkan konsep informasi akuntansi pertanggungjawaban, yang terutama bermanfaat untuk mempengaruhi perilaku manusia dalam organisasi.

\section{Biaya}

Kholmi dan Yuningsi, (2002:7), menyatakan biaya adalah pengorbanan sumber daya atau nilai ekuivalen kas yang dikorbankan untuk mendapatkan barang atau jasa yang diharapkan memberi manfaat saat sekarang atau di masa akan datang bagi organisasi. Selanjutnya pengertian biaya dikemukakan oleh Prawironegoro dan Purwanti (2009:19) bahwa "Biaya merupakan pengorbanan untuk memperoleh harta, sedangkan beban merupakan pengorbanan untuk memperoleh pendapatan. Kedua merupakan pengorbanan, namun tujuannya berbeda".

\section{Perilaku Biaya}

Simamora (2012:136) menyatakan Perilaku biaya berarti bagaimana suatu biaya akan bereaksi atau merespons perubahan tingkat aktivitas usaha. Aktivitas menunjuk kepada segala sesuatu yang dilakukan perusahaan. Perilaku biaya merupakan hal yang sangat penting bagi suatu organisasi dalam beberapa pengambilan keputusan. Manajer dapat memahami perilaku biaya melalui fungsi biaya. Fungsi biaya adalah gambaran matematis tentang bagaimana biaya berubah mengikuti perubahan tingkat aktivitas yang berhubungan dengan biaya tersebut (Horngren, Datar, Foster, George. 2008:393).

\section{Analisis Biaya Diferensial}

Biaya diferensial adalah berbagai perbedaan biaya antara sejumlah alternatif pilihan yang dapat digunakan perusahaan. Analisis biaya diferensial digunakan untuk menentukan kenaikan pendapatan, biaya, laba sehubungan dengan beberapa kemungkinan cara untuk menggunakan fasilitas tetap atau kapasitas yang tersedia

\section{Keputusan Menjual Langsung Atau Memproses Lebih Lanjut}

Mulydi menyatakan Produk bersama merupakan produk yang berasal dari input yang sama, sedangkan biaya produk bersama (joint product cost) adalah biaya yang dikeluarkan dalam memproses input menjadi produk bersama sampai pada titik pemisahan proses (spitt off point). Titik pemisahan adalah suatu tahap dimana produk bersama dapat dipisahkan menjadi produk yang berdiri sendiri dan pada saat tersebut suatu produk dapat dipasarkan langsung pada konsumen atau masih memerlukan proses lanjutan. Manajemen dihadapkan pada pilihan, memutuskan untuk menjual produk sekarang pada titik splitt off atau masih diproses lebih lanjut untuk kemudian dijual agar mendapatkan hasil yang menguntungkan.

\section{Penelitian Terdahulu}

Subekti (2006) dengan judul Analisis Biaya Diferensial Untuk Mengambil Keputusan Menjual Langsung Atau Memproses Lebih Lanjut Komuditas Apel (Studi Pada Agropolitan Batu ). Tujuan penelitian ini adalah untuk mengetahui secara jelas kegunaan biaya diferensial dalam membantu mengambil keputusan jangka pendek berkaitan dengan pembuatan keputusan menjual langsung atau memproses lebih lanjut. Metode penelitian yang digunakan dalam penelitian ini adalah metode deskriptif. Hasil penelitian menunjukkan bahwa analisis biaya diferensial menunjukkan bahwa alternatif pengolahan lebih lanjut buah apel menguntungkan dari pada menjual buah secara langsung. Persamaan dalam penelitian ini adalah sama dengan peneliti sebelumnya menggunakan biaya diferensial dalam membantu mengambil keputusan jangka pendek menjual langsung atau memproses lebih lanjut. Perbedaan dengan penelitian sebelumnya adalah terdapat pada objek yang diteliti.

Andhika (2006) dengan Judul Analisis Diferensial Sebagai Alat Bantu Manajemen Dalam Menentukan Harga Jual Pesanan Khusus. Tujuan penelitian ini adalah Untuk menerapkan analisis biaya 
diferensial sebagai salah satu alat bantu manajemen dalam pengambilan keputusan menerima atau menolak pesanan khusus. Metode yang digunakan dalam penelitian ini adalah metode deskriptif. Hasil penelitian menunjukkan bahwa dengan menerima pesanan khusus oleh konsumen perusahaan akan memperoleh tambahan laba yang lebih besar dari pada menolak pesanan. Persamaan dalam penelitian ini adalah sama dengan peneliti sebelumnya menggunakan biaya diferensial dalam membantu mengambil keputusan jangka pendek. Perbedaan dengan peneliti sebelumnya adalah terdapat pada keputusan jangka pendek, peneliti menggunakan keputusan menerima atau menolak pesanan khusus.

\section{METODE PENELITIAN}

\section{Jenis Penelitian}

Sugiyono (2010:13) menyatakan bahwa metode penelitian kualitatif adalah metode penelitian yang berlandaskan pada filsafat positivisme, metode penelitian ini digunakan untuk meneliti pada populasi atau sampel tertentu. Teknik pengambilan sampel pada umumnya dilakukan secara random, pengumpulan data menggunakan instrument penelitian, analisis data bersifat kuantitatif atau statistik dengan tujuan menguji hipotesis yang telah ditetapkan. Sedangkan metode penelitian kuantitatif adalah metode penelitian pada kondisi objek yang alamiah dimana peneliti adalah sebagai instrument kunci, pengambilan sampel sumber.Penelitian ini menggunakan penelitian Kualitatif.

\section{Tempat dan Waktu Penelitian}

Industri Kacang Sangrai Tarsius adalah suatu usaha yang bergerak dibidang perindustrian kacang yang berlokasi di Kinali Kawangkoan Jalan 17 Agustus. Waktu penelitian yang dilakukan yaitu dimulai pada awal bulan september tahun 2014 sampai selesai. Penelitian dilakukan pada saat tersebut karena penulis sedang dalam tahap penyusunan skripsi. Kegiatan penelitian yang dilakukan yaitu meninjau langsung lokasi penelitian dan mewawancarai manager dari Industri Kacang Sangrai Tarsius.

\section{Metode Pengumpulan Data}

1) Jenis Data

Data adalah sekumpulan informasi yang diperlukan untuk pengambilan keputusan. Indriantoro dan Supomo (2009 : 115) menyatakan bahwa jenis data terbagi dua yaitu :

- Data kualitatif adalah data yang disajikan dalam bentuk kata-kata yang mengandung makna dan tidak dapat dikuantitatifkan. Jenis data seperti ini berupa sejarah singkat perusahaan, struktur organisasi, proses produksi dan informasi lainnya yang relevan dengan penulisan ini.

- Data kuantitatif adalah data yang berupa angka-angka. Jenis data seperti ini berupa data yang berhubungan dengan analisis biaya diferensial untuk mengambil keputusan menjual langsung atau memprose lebih lanjut produk seperti biaya produksi, pendapatan serta data lainnya yang dapat menunjang pokok pembahasan penelitian ini.

\section{2) Sumber Data}

Indriantoro dan Supomo (2009: 146 ) menyatakan bahwa sumber data penelitian terdiri atas :

- Data primer adalah sumber data penelitian yang diperoleh secara langsung dari sumber asli.

- Data sekunder adalah sumber data penelitian yang diperoleh peneliti secara tidak langsung melalui media perantara.

\section{3) Teknik Pengumpulan Data}

Teknik pengumpulan data dilakukan dengan :

- Wawancara

Teknik pengumpulan data dengan menanyakan secara langsung mengenai gambaran umum tentang perusahaan dan mengenai segala sesuatu yang berkaitan dengan masalah yang akan dibahas. Wawancara ini dilakukan kepada pemilik usaha dari Industri Kacang sangrai Tarsius.

- Observasi

Observasi langsung untuk mengumpulkan data-data dengan cara meninjau langsung dan melakukan pengamatan proses kerja industri kacang sangrai tarsius. 


\section{- Studi Kepustakaan}

Studi kepustakaan yaitu menggunakan buku-buku dari berbagai sumber untuk mendapatkan data yang bersifat teoritis.

\section{Metode Penelitian}

Metode penelitian yang digunakan untuk membahas permasalahan dalam penelitian ini adalah metode analisis deskriptif, yaitu proses analisis yang dapat memberikan gambaran maupun uraian jelas mengenai seuatu keadaan atau fenomena, sehingga dapat ditarik kesimpulan mengenai analisis biaya diferensial dalam keputusan menjual langsung atau memproses lebih lanjut produk pada Industri kacang Sangrai Tarsius.

\section{HASIL PENELITIAN DAN PEMBAHASAN}

\section{Hasil Penelitian \\ Gambaran Umum Objek Penelitian}

Industri kacang sangrai tarsius adalah usaha yang bergerak dalam bidang perindustrian kacang sangrai. Industri kacang sangrai tarsius didirikan sejak tahun 1989 oleh keluarga Wowor - Pola sampai saat ini dan sekarang dikelolah oleh Ibu Yenny Polaak. Usaha ini bertempat di desa Kawangkoan jalan 17 agustus kinali. Produk yang dihasilkan dari industri kacang sangrai tarsius saat ini tidak hanya dipasarkan dalam desa saja tetapi telah sampai keluar desa yaitu dimasukkan dalam supermarket yang ada di Manado.

\section{Uraian Hasil Penelitian}

Dalam menjalankan suatu usaha yang paling utama adalah perencanaan. Perencanaan adalah salah satu fungsi dari manajemen untuk itu pemilik usaha dari industri kacang sangrai tarsius diharuskan untuk melakukan perencanaan dengan baik bagi kelancaran kegiatan usahanya. Setiap perencanaan pastilah dihadapkan pada berbagai pemilihan alternatif dan juga dihadapkan pada pengambilan keputusan yang menyangkut pemilihan alternatif tersebut. Dalam memutuskan alternatif mana yang akan dipilih pemilik usaha dari industri kacang sangrai tarsius akan menghadapi ketidakpastian. Untuk itu diperlukan informasi yang dapat menghindari ketidakpastian yang akan dihadapi, sehingga pemilik usaha tersebut dapat menentukan pilihan dengan baik pada alternatif yang ada. Dalam hal ini pemilik usaha tersebut telah memilih salah satu alternatif dalam perencanaan usahanya kedepan. Pemilik usaha berencana untuk memproses lebih lanjut produknya. Sebelum menerapkan alternatif tersebut dalam pengambilan keputusan menjual langsung atau memproses lebih lanjut produknya, pemilik usaha terlebih dahulu akan menganalisis dengan menyajikan data mengenai biaya bahan baku, biaya overhead, biaya tenaga kerja langsung, dan data lainya dalam produksi.

Tabel 1 Biaya Bahan Baku Untuk 1x Produksi Kacang Sangrai

\begin{tabular}{l|lc}
\hline \multicolumn{1}{c|}{ Jenis Bahan } & \multicolumn{2}{c}{ Biaya Bahan } \\
\hline Kacang Mentah & $\mathrm{Rp}$ & 2.750 .000 \\
Pasir & $\mathrm{Rp}$ & 3.000 \\
Kayu Bakar & $\mathrm{Rp}$ & 300.000 \\
\hline \multicolumn{1}{c}{ Total } & Rp & $\mathbf{3 . 0 5 3 . 0 0 0}$ \\
\hline
\end{tabular}

Sumber : Industri Kacang Sangrai Tarsius

Biaya bahan baku yang dikeluarkan pemilik usaha untuk 1 kali produksi adalah : bahan baku kacang mentah Rp 2.750.000 untuk 5 karung kacang, pasir Rp 3.000 untuk 1/2 loyang pasir, dan kayu bakar Rp 300.000 untuk 1 kubik kayu. Total yang dikeluarkan untuk bahan baku 1 kali produksi kacang sangrai adalah $\mathrm{Rp}$ 3.053.000. 
Tabel 2 Biaya Overhead Pabrik Untuk 1x Produksi Kacang Sangrai

\begin{tabular}{c|cc}
\hline \multicolumn{1}{c|}{ Biaya Overhead Pabrik } & \multicolumn{2}{|c}{ 1x Produksi Kacang Sangrai } \\
\hline Biaya tenaga kerja tidak langsung & $\mathrm{Rp}$ & 125.000 \\
Biaya Kemasan & $\mathrm{Rp}$ & 248.000 \\
\hline \multicolumn{1}{c|}{ Total BOP } & $\mathbf{R p}$ & $\mathbf{3 7 3 . 0 0 0}$ \\
\hline
\end{tabular}

Sumber : Industri Kacang Sangrai Tarsius

Tabel 2 menunjukkan biaya overhead pabrik untuk 1x produksi kacang sangrai. Untuk biaya tenaga kerja tidak langsung Rp 125.000 (25.000 x 5 karung), dan untuk biaya kemasan Rp 248.000 (4kg plastik + sablon). Total yang dikeluarkan pemilik usaha untuk biaya overhead adalah Rp 373.000 .

Tabel 3 Biaya Tenaga Kerja Langsung

\begin{tabular}{lcccccc}
\hline Jenis Tenaga Kerja & $\begin{array}{c}\text { Jumlah } \\
\text { Tenaga Kerja }\end{array}$ & $\begin{array}{c}\text { Jumlah } \\
\text { Produksi } \\
\text { (Karung) }\end{array}$ & $\begin{array}{c}\text { Upah Kerja } \\
\text { (RP) }\end{array}$ & $\begin{array}{c}\text { Biaya Tenaga Kerja } \\
\text { Langsung (RP) }\end{array}$ \\
\hline Penjemuran & 2 & 5 & $\mathrm{Rp}$ & 10.000 & $\mathrm{Rp}$ & 100.000 \\
Sangrai & 2 & 5 & $\mathrm{Rp}$ & 30.000 & $\mathrm{Rp}$ & 300.000 \\
Tapis & 2 & 5 & $\mathrm{Rp}$ & 15.000 & $\mathrm{Rp}$ & 150.000 \\
Sortir & 2 & 5 & $\mathrm{Rp}$ & 15.000 & $\mathrm{Rp}$ & 150.000 \\
\hline Total & & & & & Rp & $\mathbf{7 0 0 . 0 0 0}$ \\
\hline
\end{tabular}

Sumber : Industri Kacang Sangrai Tarsius

Biaya tenaga kerja langsung adalah semua biaya tenaga kerja yang terlibat dalam kegiatan produksi. Tenaga kerja dibagi menjadi 4 bagian yaitu penjemuran, sangrai, tapis, sortir. Pada masing-masing bagian pemilik usaha mengerjakan 2 orang. Upah yang diberikan untuk penjemuran sebesar RP $100.000(2 \times 10.000 \mathrm{x}$ 5 karung), Sangrai sebesar Rp 300.000 ( 2 x 30.000 x 5 karung), tapis sebesar Rp 150.000 ( 2 × 15.000 x 5 karung), sortir sebesar Rp 150.000 ( 2 x 15.000 x 5 karung). Total yang dikeluarkan pemilik usaha untuk membayar upah tenaga kerja langsung adalah Rp 700.000. Berdasarkan data biaya bahan baku, biaya overhead pabrik dan biaya tenaga kerja langsung diatas berikut ini akan dipisahkan biaya variabel dan biaya tetap, dimana dapat diuraikan sebagai beikut :

Tabel 4 Kalkulasi Perhitungan Biaya Variabel dan Biaya tetap

\begin{tabular}{l|cr}
\hline \multicolumn{1}{c|}{ Jenis Biaya } & \multicolumn{2}{c}{ Biaya Per Produksi } \\
\hline Biaya Variabel : & \multicolumn{2}{c}{} \\
Biaya bahan Baku & $\mathrm{Rp}$ & 3.053 .000 \\
Biaya TKL & $\mathrm{Rp}$ & 700.000 \\
\hline \multicolumn{1}{c|}{ Total Biaya Variabel } & $\mathrm{Rp}$ & 3.753 .000 \\
\hline Biaya Tetap : & $\mathrm{Rp}$ & 248.000 \\
Biaya Kemasan & $\mathrm{Rp}$ & 125.000 \\
Biaya Tenaga Kerja Tidak Langsung & $\mathrm{Rp}$ & 373.000 \\
\hline \multicolumn{1}{c|}{ Total Biaya Tetap } & $\mathrm{Rp}$ & 4.126 .000 \\
\hline \multicolumn{1}{c|}{ Total Biaya } &
\end{tabular}

Sumber : Industri Kacang Sangrai Tarsius

Hasil biaya variabel untuk biaya bahan baku sebesar Rp 3.053.000 untuk produksi 5 karung kacang, biaya tenaga kerja langsung sebesar Rp 700.000 untuk produksi 5 karung kacang. Dan untuk biaya dapat 
diuraikan sebagai berikut : untuk biaya kemasan sebesar Rp 248.000 ( harga plastik + sablon untuk 562 pack ukuran 400gram), dan biaya tenaga kerja tidak langsung senesar Rp 125.000 ( 562 pack). Dari hasil perhitungan diatas dapat dilihat bahwa total biaya variabel untuk 1x produksi sebesar $\mathrm{Rp} 3.753 .000$, total dari biaya tetap $1 \mathrm{x}$ produksi sebesar Rp 373.000. Total biaya adalah sebesar Rp 4.126.000. Berikut akan disajikan kalkulasi perhitungan pendapatan bersih menjual langsung kacang sangrai.

Tabel 5 Kalkulasi Perhitungan Bersih Menjual Langsung Kacang Sangrai

\begin{tabular}{c|c|c|c|c|c}
\hline $\begin{array}{c}\text { Banyaknya } \\
\text { Produksi }\end{array}$ & $\begin{array}{c}\text { Ukuran Jual } \\
\text { 400gram/pack }\end{array}$ & $\begin{array}{c}\text { Harga } \\
\text { jual/pack }\end{array}$ & $\begin{array}{c}\text { Total } \\
\text { Pendapatan }\end{array}$ & $\begin{array}{c}\text { Biaya-Biaya } \\
\text { Produksi }\end{array}$ & $\begin{array}{c}\text { Pendapatan } \\
\text { Bersih }\end{array}$ \\
\hline 5 Karong=225kg & 562 pack & $\begin{array}{c}\mathrm{Rp} \\
15.000\end{array}$ & $\begin{array}{c}\mathrm{Rp} \\
8.430 .000\end{array}$ & $\begin{array}{c}\mathrm{Rp} \\
4.126 .000\end{array}$ & $\mathrm{Rp} 4.304 .000$ \\
\hline \multicolumn{7}{c}{ Total Pendapatan Bersih } & $\mathrm{Rp} 4.304 .000$ \\
\hline
\end{tabular}

Sumber : Industri Kacang Sangrai Tarsius

Untuk 1x produksi kacang tarsius memproduksi 5 karung kacang mentah yang akan disangrai.Dalam 1 karung kacang ada $250 \mathrm{~kg}$ kacang dan setelah melalui proses sortir menjadi $225 \mathrm{~kg}$. Ukuran yang dipakai untuk dijual adalah $400 \mathrm{gr} /$ pack. Dalam ukuran $225 \mathrm{~kg}$ bisa mendapat 562 pack. Harga jual untuk 1 pack sebesar Rp 15.000. Jadi pendapatan yang diperoleh adalah sebesar Rp 8.430.000. Jika dikurangi dengan biaya-biaya produksi maka pendapatan bersih adalah sebesar Rp 4.304.000. Selanjutnya akan disajikan biaya proses lebih lanjut produk kacang sangrai menjadi kacang gula.

\section{Memproses Lebih Lanjut Produk Kacang Sangrai Menjadi Kacang Gula}

Berikut ini akan disajikan biaya-biaya yang akan dikeluarkan pemilik untuk proses lebih lanjut produknya : Tabel 6 menunjukkan biaya bahan baku yang harus dikeluarkan pemilik usaha jika ingin memproses lebih lanjut produknya adalah Biaya bahan baku untuk gula merah sebesar Rp 1440.000 (Untuk 80kg gula merah dengan harga Rp 18.000/kg) dan biaya kayu bakar sebesar Rp 300.000 (proses produksi untuk 5 karung kacang). Total yang harus dikeluarkan pemilik usaha untuk bahan baku adalah sebesar Rp 1.740.000.

Tabel 6 Biaya Bahan Baku Untuk Memproses Lebih Lanjut

\begin{tabular}{|c|c|c|}
\hline Jenis Bahan & \multicolumn{2}{|c|}{ Biaya Bahan } \\
\hline Gula Merah & $\mathrm{Rp}$ & 1.440 .000 \\
\hline Kayu Bakar & $\mathrm{Rp}$ & 300.000 \\
\hline Total & $\mathrm{Rp}$ & 1.740 .000 \\
\hline
\end{tabular}

Sumber : Data yang diolah

Selanjutkan akan disajikan biaya overhead pabrik untuk proses lebih lanjut produk yaitu sebagai berikut :

Tabel 7 Biaya overhead Pabrik Untuk Proses Lebih Lanjut

\begin{tabular}{l|lr}
\hline \multicolumn{1}{c|}{ Biaya Overhead Pabrik } & \multicolumn{2}{c}{ Proses Lebih Lanjut Produk } \\
\hline Biaya tenaga kerja tidak langsung & $\mathrm{Rp}$ & 125.000 \\
Biaya Kemasan & $\mathrm{Rp}$ & 480.000 \\
Biaya Pajak + Listrik & $\mathrm{Rp}$ & 300.000 \\
Biaya Distribusi & $\mathrm{Rp}$ & 155.000 \\
\hline \multicolumn{1}{c|}{ Total BOP } & $\mathbf{R p}$ & $\mathbf{1 . 0 6 0 . 0 0 0}$ \\
\hline
\end{tabular}

Sumber : Data yang diolah 
Tabel 7 menunjukkan biaya overhead pabrik yang harus dikeluarkan pemilik jika memproses lebih lanjut produknya. Untuk biaya tenaga keja tidak langsung sebesar Rp 125.000 (25.000 x 5 karung), biaya kemasan Rp 480.000, biaya pajak + listrik sebesar Rp 300.000 dan biaya distribusi sebesar Rp 155.000. Total biaya overhead yang harus dikeluarkan pemilik adalah sebesar Rp 1.060.000. Selanjutnya akan disajikan data biaya tenaga kerja langsung untuk proses lebih lanjut produk :

\section{Tabel 8 Biaya Tenaga Kerja Langsung Untuk Proses Lebih Lanjut}

\begin{tabular}{|c|c|c|c|c|c|c|}
\hline Jenis Tenaga Kerja & $\begin{array}{l}\text { Jumlah } \\
\text { Tenaga Kerja }\end{array}$ & $\begin{array}{l}\text { Jumlah } \\
\text { Produksi } \\
\text { (Karung) }\end{array}$ & \multicolumn{2}{|c|}{$\begin{array}{l}\text { Upah Kerja } \\
\text { (RP) }\end{array}$} & \multicolumn{2}{|c|}{$\begin{array}{l}\text { Biaya Tenaga Kerja } \\
\text { Langsung (RP) }\end{array}$} \\
\hline Pengupasan & 1 & 5 & $\mathrm{Rp}$ & 75.000 & $\mathrm{Rp}$ & 375.000 \\
\hline Pencampuran & 1 & 5 & $\mathrm{Rp}$ & 80.000 & $\mathrm{Rp}$ & 400.000 \\
\hline Total & & & & & $\mathbf{R p}$ & 775.000 \\
\hline
\end{tabular}

Sumber : Data yang diolah

Biaya tenaga kerja langsung untuk proses lebih lanjut produk dihitung berdasarkan jumlah yang diproduksi. Tenaga kerja langsung dibagi menjadi 2 bagian yaitu pengupasan dan pencampuran. Pada masingmasing bagian hanya 1 tenaga kerja. Upah yang diberikan untuk bagian pengupasan adalah sebesar Rp 375.000 (Rp 75.000 x 5 karung) dan upaj untuk bagian pencampuran adalah sebesar Rp 400.000 ( Rp 80.000 × 5 karung). Total biaya yang harus dikeluarkan pemilik usaha untuk membayar upah tenaga kerja langsung adalah sebesar Rp 775.000.

Berdasarkan data biaya bahan baku langsung dan biaya overhead pabrik dan biaya tenaga kerja langsung untuk proses lebih lanjut produk diatas berikut ini akan pisahkan biaya variabel dan biaya tetap, dimana dapat diuraikan sebagai berikut:

Tabel 9 Kalkulasi Perhitungan Biaya Variabel dan Biaya tetap Untuk Proses Lebih Lanjut

\begin{tabular}{l|lr}
\hline \multicolumn{1}{c|}{ Jenis Bahan } & \multicolumn{2}{c}{ Biaya Per Produksi } \\
\hline Biaya Variabel : & \multicolumn{2}{c}{} \\
Biaya bahan Baku & $\mathrm{Rp}$ & 1.740 .000 \\
Biaya TKL & $\mathrm{Rp}$ & 775.000 \\
\hline \multicolumn{1}{c|}{ Total Biaya Variabel } & $\mathrm{Rp}$ & 2.515 .000 \\
\hline Biaya Tetap : & & 480.000 \\
Biaya Kemasan & $\mathrm{Rp}$ & 125.000 \\
Biaya Tenaga Kerja Tidak Langsung & $\mathrm{Rp}$ & 300.000 \\
Biaya Pajak +Listrik & $\mathrm{Rp}$ & 155.000 \\
Biaya Distribusi & $\mathrm{Rp}$ & 1.060 .000 \\
\hline \multicolumn{1}{c|}{ Total Biaya Tetap } & $\mathrm{Rp}$ & 3.575 .000 \\
\hline \multicolumn{1}{c|}{ Total Biaya } & $\mathrm{Rp}$ &
\end{tabular}

Sumber : Data yang diolah

Hasil biaya variabel untuk biaya bahan baku sebesar Rp 1.740 .000 untuk proses lebih lanjut produk 5 karung kacang, biaya tenaga kerja langsung sebesar Rp 775.000 untuk prose lebih lanjut produk 5 karung kacang. Dan untuk biaya tetap dapat diuraikan sebagai berikut : untuk biaya pengemasan sebesar Rp 480.000 (harga plastik + sablon untuk 762 pack ukuran 400gram), dan biaya tenaga kerja tidak langsung sebesar Rp 125.000 (762 pack). Dari hasil perhitungan diatas dapat dilihat bahwa total biaya variabel untuk proses lebih 
lanjut produk sebesar $\mathrm{Rp}$ 2.515.000, total dari biaya tetap untuk proses lebih lanjut produk sebesar $\mathrm{Rp}$ 1.060.000. Total biaya adalah sebesar Rp 3.575.000.

Jika pemilik usaha memproses lebih lanjut 5 karung kacang yang telah disangrai menjadi kacang gula maka $225 \mathrm{~kg}$ kacang sangrai untuk 5 karung akan menjadi $305 \mathrm{~kg}$ kacang gula. Dalam ukuran $305 \mathrm{~kg}$ kacang gula akan mendapat 762 pack ukuran 400gram. Harga jual untuk 1 pack ukuran 400gram kacang gula adalah Rp 20.000. Jadi pendapatan yang diperoleh jika menjual 762 pack kacang gula adalah sebesar Rp 15.240.000. Jika dikurangi dengan biaya-biaya selama produksi maka pendapatan bersih untuk kacang gula adalah Rp 7.912.000. Berikut ini akan disajikan kalkulasi perhitungan pendapatan bersih proses lebih lanjut kacang sangrai menjadi kacang gula adalah sebagai berikut :

Tabel 10 Kalkulasi Perhitungan Pendapatan Bersih Proses lebih Lanjut

\begin{tabular}{c|c|c|c|c|c}
\hline $\begin{array}{c}\text { Banyaknya } \\
\text { Produksi }\end{array}$ & $\begin{array}{c}\text { Ukuran Jual } \\
\text { 400gram/pack }\end{array}$ & $\begin{array}{c}\text { Harga } \\
\text { jual/pack }\end{array}$ & $\begin{array}{c}\text { Total } \\
\text { Pendapatan }\end{array}$ & $\begin{array}{c}\text { Biaya-Biaya } \\
\text { Produksi }\end{array}$ & $\begin{array}{c}\text { Pendapatan } \\
\text { Bersih }\end{array}$ \\
\hline 5 Karong=305kg & 762 pack & $\begin{array}{c}\mathrm{Rp} \\
20.000\end{array}$ & $\begin{array}{c}\mathrm{Rp} \\
15.240 .000\end{array}$ & $\begin{array}{c}\mathrm{Rp} \\
7.328 .000\end{array}$ & $\mathrm{Rp} 7.912 .000$ \\
\hline \multicolumn{7}{c}{ Total Pendapatan Bersih } & Rp7.912.000 \\
\hline
\end{tabular}

Sumber : Data yang diolah

\section{Pembahasan}

Salah satu yang menjadi faktor utama dari kegagalan yang dialami oleh suatu perusahaan adalah kesalahan dari pihak manajemen dalam mengambil keputusan. Setiap keputusan yang diambil oleh pihak manajemen akan menjadi tolak ukur keberhasilan dari suatu perusahaan dimasa yang akan datang. Pengambilan keputusan pada hakekatnya merupakan pemilihan diantara serangkaian alternatif. Para manager dihadapkan pada pengambilan keputusan yang menyangkut pemilihan berbagai macam alternatif. Dalam hal ini pemilik usaha industri kacang sangrai tarsius dihadapkan pada alternatif menjual langsung atau memproses lebih lanjut produknya. Untuk itu pemilik usaha membutuhkan informasi dalam menentukan pilihan terbaik bagi usahanya.

Untuk pengambilan keputusan yang tepat maka diperlukan informasi yang relevan berkaitan dengan alternatif yang akan dipilih. Jadi informasi yang relevan yang harus diperhatikan oleh pemilik usaha adalah biaya dan pendapatan dari masing-masing alternatif dan membandingkanya untuk melihat besarnya laba/pendapatan yang dihasilkan antara menjual langsung atau memproses lebih lanjut. Tujuan dari penelitian ini adalah memberikan informasi yang relevan bagi pemilik usaha untuk mengetahui biaya-biaya apa saja yang akan dikeluarkan jika keputusan proses lebih lanjut diterapkan.

Dari data-data yang telah dilampirkan diatas kita bisa melihat bahwa jika pemilik usaha memproses lebih lanjut produknya dari kacang sangrai menjadi kacang gula pendapatan yang diperoleh lebih dari pendapatan jika langsung menjualnya. Berikut adalah iktisar dari analisis diferensial untuk keputusan menjual langsung atau memproses lebih lanjut produk:

Tabel 11 Analisis Diferensial Untuk Keputusan Menjual Langsung Atau Memproses Lebih lanjut

\begin{tabular}{lccccc}
\hline Ket : & Menjual & $\begin{array}{c}\text { Memproses Lebih } \\
\text { lanjut }\end{array}$ & $\begin{array}{c}\text { Jumlah } \\
\text { Diferensial Bila } \\
\text { Mmeproses lebih } \\
\text { Lanjut }\end{array}$ \\
\hline Pendapatan Bersih & Rp & 4.304 .000 & Rp & 11.487 .000 & Rp 7.183 .000 \\
Biaya Pemrosesan & Rp & - & Rp & 3.575 .000 & Rp 3.575.000 \\
Keuntungan & Rp & 4.304 .000 & Rp & 7.912 .000 & Rp 3.608.000 \\
\hline
\end{tabular}

Sumber : Data yang diolah 
Dari tabel 11 bisa kita lihat pendapatan bersih dari penjualan langsung kacang sangrai sebanyak 562 pack adalah sebesar Rp 4.304.000 dan pendapatan bersih dari penjualan proses lebih lanjut menjadi kacang gula sebanyak 762 pack adalah sebesar Rp 11.487.000 jumlah diferensial dari pendapatan bersih adalah sebesar Rp 7.183.000. Biaya pemrosesan yang akan dikeluarkan jika ingin memproses lebih lanjut produk adalah sebesar Rp 3.575.000. Keuntungan yang diterima jika pemilik menjual langsung produknya adalah sebesar Rp 4.304.000. Jika pemilik memproses lebih lanjut produknya maka keuntungan yang akan diterima adalah sebesar Rp 7.912.000. Selisih keuntungan antara menjual langsung dan memproses lebih lanjut produk adalah sebesar Rp 3.608.000. Jadi keputusan untuk memproses lebih lanjut produk kacang sangrai menjadi kacang gula bisa diterapkan karena pendapatan yang dihasilkan lebih dari menjual langsung.

\section{KESIMPULAN}

Kesimpulan dari penelitian ini adalah pemilik usaha dalam mengembangkan usahanya dengan memilih alternatif memproses lebih lanjut produk bisa diterapkan, karena jika diproses lebih lanjut produknya maka pendapatan yang akan diterima lebih menguntungkan.

\section{Saran}

Berdasarkan kesimpulan diatas maka yang dapat penulis sarankan untuk pemilik usaha industri kacang sangrai tarsius adalah keputusan untuk memproses lebih lanjut produknya sudah benar karena laba/pendapatan yang dihasilkan lebih besar dari pada keputusan menjual langsung. Untuk itu jika ingin mendapatan laba/pendapatan yang lebih maka keputusan untuk proses lebih lanjut sudah bisa diterapkan.

\section{DAFTAR PUSTAKA}

Andhika, Arry Candra. 2006. Analisis Biaya Diferensial Sebagai Alat Bantu Manajemen Dalam Menentukan Harga Jual Pesanan Khusus. http://skripsi.umm.ac.id/files/disk1/149/jiptummpp-gdl-s1-2006arrychandr-7426-PENDAHUL-N.pdf Diakses tanggal 24 mei 2014

Halim, Abdul, Supomo, Bambang, Kusufi, Muhammad. 2013. Akuntansi manajemen (akuntansi manajerial). Edisi kedua. Penerbit BPFE. Yogyakarta.

Hongren, Datar, M, Foster, Goerge . 2008. Akuntansi biaya dengan pendekatan manjrial. Jilid 1. Edisi 12. Penerbit erlangga. Jakarta.

Indriantoro Nur M,Sc, Drs. Supomo Bambang M.Si. 2013. Metodologi Penelitian Bisnis Untuk Akuntansi \& Manajemen. Edisi Pertama. Penerbit BPFE Yogyakarta. Yogyakarta.

Indriantoro, Supomo. 2009. Metodologi Penelitian Bisnis Untuk Akuntansi \& Bisnis. Edisi Pertama. BPFE : Yogyakarta.

Jusup Al Haryono M.B.A. 1999. Dasar-Dasar Akuntansi. Jilid 1. Edisi Kelima. Penerbit Sekolah Tinggi Ilmu Ekonomi YKPN. Yogyakarta.

Kamaruddin,Ahmad. 2005. Akuntansi Manajemen Dasar-Dasar Konsep Biaya Dan Pengambilan Keputusan. edisi revisi ketiga. Raja Grafindo Persada. Jakarta.

Kholmi, Masiyah., Yuningsih. 2002. Akuntansi Biaya. edisi pertama. cetakan kedua. Universitas Muhammadiyah. Malang.

Maher Michael W, Deakin Edward B, 1996.Analisis Biaya Diferensial Jilid 1. Edisi Keempat. Erlangga. Jakarta

Mulyadi. 2001. Akuntansi Manajemen : Konsep, Manfaat, dan rekayasa. Edisi ketiga. Salemba Empat. Jakarta. 
Prawironegoro, Darsono., Purwanti Ari. 2009. Akuntansi Manajemen. Edisi Ketiga. Mitra Wacana Media. Jakarta.

Simamora, Hendry. 2012. Akuntansi Manajemen. Edisi ketiga. Cetakan ketiga. Star Gate Publisher Riau.

Subekti, Lucky. 2006. Analisis Biaya Diferensial Untuk Mengambil Keputusan Menjual Langsung atau Memproses Lebih Lanjut Komuditas apel (Studi Pada Agropolitan Batu) http://skripsi.umm.ac.id/files/disk1/138/jiptummpp-gdl-s1-2006-lukkysubek-6865-PENDAHUL-N.pdf . Diakses tanggal 24 mei 2014

Sugiyono. 2010. Metode penelitian Kuantitatif Kualitatif dan R\&D. Alfabeta. Jakarta.

Sugiarto. 1999. Pengantar Akuntansi I. Universitas Terbuka. Jakarta.

Supriyono. 1994. Akuntansi Biaya dan Akuntansi Manajemen Untuk Teknologi maju dan Globalisasi. BPFE. Yogyakarta.

Warindrani,Armila Krisna 2006. Akuntansi Manajemen. edisi Pertama. Graha Ilmu. Yogyakarta. 